\title{
SCOUR NEAR SPILL-THROUGH TYPE ABUTMENT ON CLEAR-WATER SCOUR CONDITION FOR MULTI-SECTION CHANNELS
}

\author{
by Jaji Abdurrosyid ${ }^{1}$ and Achmad Karim Fatchan ${ }^{2}$
}

\begin{abstract}
Scour is a natural phenomenon caused by erosion due to water flow on the alluvial channel bed and channel wall. In fact, scour happened in the bridge abutment is total scour, that is a combination between local scour, general scour, and constriction scour. This research aims to find the depth of scour near abutment in clear-water scour condition. This research was carried out using recirculation flume. The channel model was a compound channel and using steady-uniform flow. The abutment model was Spill-Through type (ST). The depth of scour near abutment was measured in each 6 hours running at 9 point of position. The research result shows that the maximum scour depth happened at point of separation. The depth of scour is mostly affected by Reynold and Froude number of flow. In general, the scour pattern happened around abutment is the same at every running which can be seen in the scour contour pattern that has half horseshoe shape.
\end{abstract}

Keywords: clear-water scour; depth of scour; scour pattern.

\section{PENDAHULUAN}

Gerusan adalah merupakan fenomena alami yang disebabkan oleh erosi akibat aliran air pada dasar dan tebing saluran alluvial. ${ }^{1}$ Juga merupakan proses menurunnya atau semakin dalamnya dasar sungai di bawah elevasi permukaan alami (datum) karena interaksi antara aliran dengan material dasar sungai. Proses penggerusan akan terjadi secara alami, baik karena pengaruh morfologi sungai seperti tikungan sungai atau penyempitan aliran sungai, atau pengaruh bangunan hidraulika yang menghalangi aliran seperti abutmen jembatan. $^{2}$

Menurut Rawiyah danYulistiyanto, ${ }^{3}$ gerusan yang terjadi disekitar abutmen merupakan akibat sistem pusaran (vortex system) yang timbul karena aliran dirintangi oleh bangunan tersebut. Sistem pusaran yang menyebabkan lubang gerusan (scour hole) berawal dari sebelah hulu abutmen yaitu pada saat mulai timbul komponen aliran dengan arah aliran ke bawah. Karena aliran yang datang dari hulu dihalangi oleh abutmen, maka aliran akan berubah arah menjadi arah vertikal menuju dasar saluran dan sebagian berbelok arah menuju depan abutmen selanjutnya diteruskan ke hilir. Aliran arah vertikal ini akan terus menuju dasar yang selanjutnya akan membentuk pusaran. Di dekat dasar saluran komponen aliran berbalik arah vertikal ke atas, peristiwa ini diikuti dengan terbawanya material dasar sehingga terbentuk aliran sepiral yang akan menyebabkan gerusan dasar. Hal ini akan terus berlanjut hingga tercapai keseimbangan. $^{3}$

\footnotetext{
${ }^{1}$ Staf pengajar jurusan Teknik Sipil, Fakultas Teknik, Universitas Muhammadiyah Surakarta Jl. A. Yani No. 1 Tromol Pos 1, Pabelan Kartasura, Surakarta 57102.

${ }^{2}$ Staf pengajar jurusan Teknik Sipil, Fakultas Teknik, Universitas Muhammadiyah Surakarta Jl. A. Yani No. 1 Tromol Pos 1, Pabelan Kartasura, Surakarta 57102.

Note. The manuscript for this paper was submitted for review and possible publication on May 18, 2009; approved on October 26, 2009. Discussions open until February 2010. This paper is part of the ITS Journal of Civil Engineering, Vol. 29, No.1, May 2009. (C) ITS Journal of Civil Engineering, ISSN 2086-1206/2009.
}

Gerusan yang terjadi pada abutmen maupun pilar jembatan adalah merupakan gerusan total (total scour), yaitu kombinasi antara gerusan lokal (local scour) dan gerusan umum (general scour). Dapat juga kombinasi antara gerusan lokal, gerusan umum dan gerusan terlokalisir atau penyempitan (constriction scour). Gerusan lokal yang terjadi di sekitar abutmen jembatan ataupun pilar disebabkan oleh sistem pusaran air (vortex system) karena adanya gangguan pola aliran akibat rintangan, dan gerusan terlokalisir terjadi karena adanya penyempitan penampang sungai oleh adanya penempatan bangunan hidraulika. Sedangkan gerusan umum yang terjadi melintang sungai di sepanjang saluran yang menyebabkan degradasi dasar disebabkan oleh energi dari aliran air. ${ }^{4}$

Proses gerusan bisa menyebabkan erosi dan degradasi disekitar jembatan. Degradasi ini berlangsung secara terus menerus hingga dicapai keseimbangan antara suplai dan angkutan sedimen yang saling memperbaiki. Apabila suplai sedimen dari hulu berkurang atau jumlah angkutan sedimen lebih besar daripada suplai sedimen, maka bisa menyebabkan terjadinya kesenjangan yang begitu menyolok antara degradasi dan agradasi di daerah fondasi jembatan. Sehingga lubang gerusan (scour hole) pada abutmen maupun pilar jembatan akan lebih dalam bila tidak terdapat atau kurangnya suplai sedimen. Hal ini bisa menyebabkan rusaknya abutmen maupun pilar jembatan. Untuk itu, maka perlu adanya kajian laboratorium mengenai gerusan total yang terjadi di sekitar abutmen jembatan pada saluran majemuk seperti keadaan sungai alami di lapangan, hal ini bermanfaat sekali dalam perencanaan dalamnya fondasi jembatan.

Penelitian ini bertujuan untuk mengetahui kedalaman gerusan dan pola gerusan yang terjadi di sekitar abutmen pada kondisi aliran jernih (clear-water scour) untuk saluran dengan penampang berbentuk majemuk (compound channel) pada abutmen tipe Spill-Trough.

Penelitian serupa tentang gerusan (scour) baik itu pada pilar maupun abutmen jembatan pernah dilakukan oleh para peneliti terdahulu yang kebanyakan meneliti tentang gerusan pada pilar jembatan seperti halnya Breuseurs dan Raudkivi. $^{5}$ Sedang penelitian tentang abutmen diantaranya Hanwar, ${ }^{6}$ Rinaldi, ${ }^{7}$ dan Abdurrosyid. ${ }^{8}$

Melville meneliti tentang kedalaman gerusan di sekitar abutmen jembatan pada saluran majemuk 
(compound channel) dengan menggunakan tipe wing-wall abutment. Penelitian dilakukan dengan membandingkan antara saluran persegi (rectangular channel) dengan saluran majemuk pada kondisi live-bed scour. Hasil penelitian menunjukkan bahwa kedalaman gerusan pada saluran majemuk lebih kecil bila dibandingkan pada saluran persegi. ${ }^{9}$ Hanwar meneliti tentang gerusan lokal di sekitar abutmen jembatan dengan menggunakan tipe semi-circular-end (SCE) pada saluran prismatis dalam kondisi clear-water scour dan live-bed scour. ${ }^{6}$ Rinaldi meneliti tentang proteksi gerusan pada abutmen tipe SCE dengan kondisi aliran clear-water scour dan bentuk saluran prismatis segi empat. Proteksi gerusan menggunakan pelat, dengan variasi jarak pelat terhadap dasar, variasi lebar pelat dan variasi sudut pelat. ${ }^{7}$

Abdurrosyid meneliti tentang pengendalian gerusan pada model abutmen tipe sphill-through dengan menggunakan plat, tirai dan groundsill sebagai pelindung pada kondisi live-bed scour untuk saluran prismatis segi empat. ${ }^{8}$ Sedangkan kajian pada tulisan ini yaitu mengenai penelitian kedalaman gerusan pada abutmen tipe sphillthrough serta pola gerusannya pada kondisi aliran clearwater scour dan pada saluran berpenampang majemuk. ${ }^{10}$ Jadi penelitian ini diilhami oleh penelitian yang pernah dilakukan oleh Melville yang menggunakan saluran berpenampang majemuk, akan tetapi model yang digunakan adalah tipe sphill-through dan aliran yang ditinjau adalah aliran clear-water scour.

Pengertian clear-water scour adalah aliran yang terjadi secara kasat mata nampak jernih, aliran ini mempunyai tegangan gesek dasar saluran lebih kecil dari tegangan gesek kritisnya, pada kondisi ini belum ada gerusan/angkutan sedimen dasar bila saluran tidak terdapat penghalang/bangunan hidraulika, ketika penghalang dipasang maka akan terjadi gerusan lokal. Sedangkan live-bed scour adalah apabila aliran mempunyai tegangan gesek lebih besar dari tegangan gesek kritisnya maka aliran mengalir disertai dengan pergerakan sedimen dan nampak aliran menjadi keruh. ${ }^{1}$ Sedangkan saluran majemuk adalah saluran yang mempunyai penampang berbentuk variatif, tidak persegi (rectangular channel) dan tidak prismatis. Saluran ini bisa merupakan kombinasi dua persegi yang berbeda luas tampangnya, bisa juga berbentuk saluran alami. ${ }^{9}$

Menurut Breusers dan Raudkivi, kedalaman gerusan $\left(\mathrm{d}_{\mathrm{s}}\right)$ tergantung dari beberapa variabel, yaitu karakterisitik fluida, material dasar, aliran dalam saluran dan bentuk pilar atau abutmen jembatan yang dapat ditulis: ${ }^{5}$

$$
d_{S}=f\left(\rho, v, g, d, \rho_{S}, h_{0}, U, L_{b}\right)
$$

Dengan $\rho=$ rapat massa fluida, $v=$ kekentalan kinematik fluida, $g=$ percepatan gravitasi, $d=$ diameter butiran sediment, $\rho_{\mathrm{s}}=$ rapat massa sedimen, $h_{0}=$ kedalaman aliran, $U=$ kecepatan aliran rata-rata, $L_{b}=$ lebar abutmen. Jika persamaan tersebut dibuat tidak berdimensi, maka persamaan menjadi :

$$
\frac{d_{s}}{L_{b}}=f\left(\frac{U L b}{v}, \frac{U^{2}}{g L_{b}}, \frac{h_{0}}{L_{b}}, \frac{d}{L_{b}}, \Delta\right)
$$

atau

$$
\frac{d_{s}}{L_{b}}=f\left(\frac{U_{*} L_{b}}{v}, \frac{U_{*}^{2}}{g d \Delta}, \frac{h_{0}}{L_{b}}, \frac{d}{L_{b}}, \Delta\right)
$$

dengan $\Delta=$ rapat massa relatif dari butiran terendam,

$$
\Delta=\frac{\rho_{s}-\rho}{\rho}
$$

dengan,

$$
\begin{aligned}
d_{s} \frac{d_{s}}{L_{b}}=f\left(\frac{U_{*} L_{b}}{v}, \frac{U_{*}^{2}}{g d \Delta}, \frac{h_{0}}{L_{b}}, \frac{d}{L_{b}}, \Delta\right) & =\text { kedalaman gerusan } \\
U_{*} & =\text { kecepatan gesek }
\end{aligned}
$$

Menurut Melville, kedalaman gerusan lokal setelah mencapai keseimbangan $\left(d_{s e}\right)$ pada abutmen dapat ditulis sebagai berikut: ${ }^{9}$

$$
d_{s e}=f\left(\rho, v, g, d_{50}, \rho_{S}, h_{0}, U, L_{b}, \sigma_{g}, S h, A l, G\right)
$$

dengan $d_{50}=$ diameter rerata butiran, $\sigma_{g}=$ deviasi standar geometri dari distribusi ukuran butiran sedimen, $S h=$ parameter bentuk, $A l=$ parameter alinemen abutmen, dan $G=$ parameter pengaruh dari distribusi aliran lateral dan bentuk penampang lintang saluran. Dengan asumsi rapat massa relatif sedimen adalah konstan dan pengaruh kekentalan ditiadakan, maka persamaan (4) dapat ditulis dalam persamaan tidak berdimensi sebagai berikut :

$$
\frac{d_{s e}}{L b}=f\left(\frac{U^{2}}{g d_{50}}, \frac{h_{0}}{L_{b}}, \frac{d_{50}}{L_{b}}, \sigma_{g}, S h, A l, G\right)
$$

atau

$$
\frac{d_{s e}}{h_{0}}=f\left(\frac{U^{2}}{g d_{50}}, \frac{L b}{h_{0}}, \frac{d_{50}}{h_{0}}, \sigma_{g}, S h, A l, G\right)
$$

Dimana persamaan (5) lebih dapat digunakan untuk abutmen pendek, dan persamaan (6) lebih baik digunakan untuk abutmen panjang. Istilah abutmen panjang (long abutment), didefinisikan sebagai abutmen yang mempunyai nilai $\frac{L_{b}}{h_{0}} \geq 25$; dan abutmen pendek (short abutment), didefinisikan sebagai abutmen yang mempunyai nilai $\frac{L_{b}}{h_{0}} \leq 1$.

Shen 1971, menghubungkan kedalaman gerusan dengan bilangan Reynold pilar/abutmen $\left(\mathrm{R}_{\mathrm{p}}=\mathrm{Ub} / \mathrm{v}\right){ }^{2}$ sedangkan Garde dan Raju mempertimbangkan bilangan Froud $\left(F_{r}\right)$ sebagai parameter yang berpengaruh terhadap kedalaman gerusan. Studi tersebut menunjukkan bahwa kecepatan, kedalaman aliran dan lebar pilar/abutmen dapat mempengaruhi kedalaman gerusan. ${ }^{11}$

Laursen 1962 menemukan bahwa pada gerusan dengan aliran angkutan sedimen (live-bed scour), pengaruh kecepatan aliran terhadap gerusan adalah kecil, tetapi kedalaman aliran sangat mempengaruhi kedalaman gerusan. Sedangkan pada gerusan aliran jernih (clear water scour), kecepatan aliran sangat berpengaruh terhadap kedalaman gerusan. ${ }^{9}$ 
Tabel 1. Kedalaman gerusan seimbang $\left(\mathrm{d}_{\mathrm{s}}\right)$ pada clear-water scour

\begin{tabular}{ccccccccccc}
\hline No & Debit & \multicolumn{7}{c}{ Kedalaman gerusan seimbang $\left(\mathrm{d}_{\mathrm{s}}\right), \mathrm{cm}}$. \\
\cline { 3 - 11 } Running & lt/dt & Pos.1 & Pos.2 & Pos.3 & Pos.4 & Pos.5 & Pos.6 & Pos.7 & Pos.8 & Pos. 9 \\
\hline 1 & 10 & 5 & -0.07 & -0.43 & -0.25 & -0.16 & -0.16 & -0.07 & 0 & 5 \\
2 & 12 & 5 & -0.13 & -1.02 & -0.27 & -0.22 & -0.16 & -0.06 & -0.08 & 5 \\
3 & 15 & 5 & -0.25 & -2.22 & -1.42 & -0.43 & -0.34 & -0.12 & -0.12 & 5 \\
4 & 17 & 5 & -0.49 & -3.43 & -2.39 & -0.59 & -0.41 & -0.17 & -0.14 & 5 \\
5 & 20 & 5 & -1.42 & -4.82 & -3.21 & -0.79 & -0.56 & -0.16 & -0.17 & 5 \\
6 & 23 & 5 & -4.1 & -5.89 & -4.1 & -2.31 & -0.7 & -0.52 & -0.19 & 5 \\
7 & 25 & 5 & -4.56 & -7.25 & -5.83 & -2.92 & -1.85 & -0.91 & -0.68 & 5 \\
8 & 27 & 5 & -7.09 & -8.21 & -6.69 & -4.32 & -2.7 & -1.38 & -0.81 & 5 \\
9 & 28 & 5 & -8.9 & -8.66 & -7.12 & -5.26 & -3.26 & -1.71 & -0.88 & 5 \\
10 & 30 & 5 & -9.02 & -10 & -8.57 & -7.77 & -6.34 & -3.21 & -1.09 & 5 \\
\hline
\end{tabular}

Tabel 2. Lebar dan panjang lubang gerusan pada kontur, serta hubungannya

\begin{tabular}{|c|c|c|c|c|c|c|c|c|c|}
\hline No & $\begin{array}{l}\text { Q } .10^{-3} \\
\left(\mathrm{~m}^{3} / \mathrm{dt}\right)\end{array}$ & $\begin{array}{c}\mathrm{U}_{*} \\
(\mathrm{~m} / \mathrm{dt})\end{array}$ & $\begin{array}{c}\mathrm{L} \\
(\mathrm{m})\end{array}$ & $\begin{array}{c}\mathrm{P} \\
(\mathrm{m})\end{array}$ & $\begin{array}{c}\mathrm{U} \\
(\mathrm{m} / \mathrm{dt})\end{array}$ & $\overline{\mathrm{U} / \mathrm{U}^{*}}$ & $\begin{array}{c}\mathrm{d}_{\mathrm{s}} \\
(\mathrm{m})\end{array}$ & $\overline{\mathrm{L} / \mathrm{d}_{\mathrm{s}}}$ & $\mathrm{P} / \mathrm{d}_{\mathrm{s}}$ \\
\hline 1 & 10 & 0.00548 & 0.58 & 0.85 & 0.091 & 16.605839 & 0.0043 & 134.88372 & 197.67442 \\
\hline 2 & 12 & 0.00668 & 0.64 & 0.9 & 0.111 & 16.616766 & 0.0102 & 62.745098 & 88.235294 \\
\hline 3 & 15 & 0.00837 & 0.76 & 0.96 & 0.141 & 16.845878 & 0.0222 & 34.234234 & 43.243243 \\
\hline 4 & 17 & 0.00924 & 0.77 & 0.99 & 0.159 & 17.207792 & 0.0343 & 22.44898 & 28.862974 \\
\hline 5 & 20 & 0.01096 & 0.78 & 1.05 & 0.188 & 17.153285 & 0.0482 & 16.182573 & 21.784232 \\
\hline 6 & 23 & 0.01226 & 0.82 & 1.25 & 0.216 & 17.618271 & 0.0589 & 13.921902 & 21.222411 \\
\hline 7 & 25 & 0.01335 & 0.84 & 1.28 & 0.235 & 17.602996 & 0.0725 & 11.586207 & 17.655172 \\
\hline 8 & 27 & 0.01438 & 0.85 & 1.31 & 0.254 & 17.663421 & 0.0821 & 10.353228 & 15.956151 \\
\hline 9 & 28 & 0.01489 & 0.85 & 1.33 & 0.263 & 17.662861 & 0.0866 & 9.8152425 & 15.357968 \\
\hline 10 & 30 & 0.01583 & 0.86 & 1.35 & 0.282 & 17.814277 & 0.1 & 8.6 & 13.5 \\
\hline
\end{tabular}

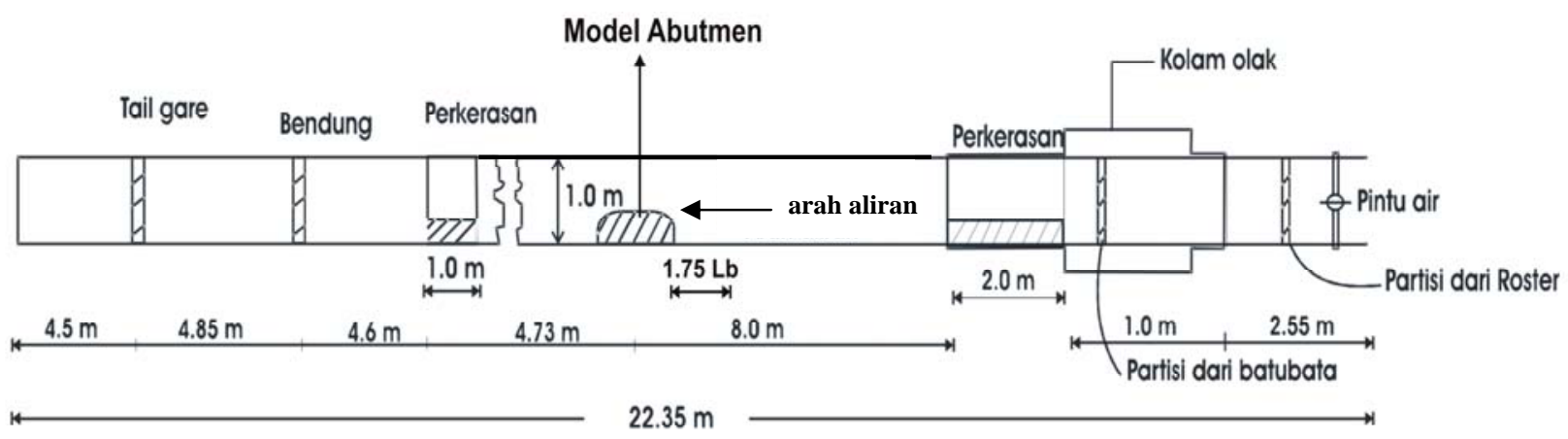

Gambar 1. Tampak atas flume.

\section{METODE PENELITIAN}

Penelitian dilakukan di Laboratorium Hidraulika Balai Penyelidikan Sungai Surakarta (Jl. Ahmad Yani, Pabelan Kartasura, Surakarta) dengan menggunakan sedimentrecirculating flume dengan lebar saluran $100 \mathrm{~cm}$ dan panjang saluran 22,35 $\mathrm{m}$ (panjang total dari pintu intake sampai tail-gate $=25,9 \mathrm{~m}$ ), tinggi flume $=0,45 \mathrm{~m}$, kemiringan saluran permanen dengan slope $=0,0004$, debit aliran dari pompa maksimum $150 \mathrm{l} / \mathrm{det}$. Posisi model abutmen diletakkan pada jarak as sejauh 14,18 m dari tail gate di hilir flume dan jarak as sejauh $10 \mathrm{~m}$ dari kolam olak hal ini untuk menghindari pengaruh gelombang dari kolam olak, seperti yang terlihat pada Gambar 1 dan Gambar 2 (lihat lampiran). Model abutmen adalah tipe Spill-trough (ST) seperti yang terlihat pada Gambar 3. Tipe ST mempunyai dimensi yaitu lebar abutment, $L_{b}=40 \mathrm{~cm}$, panjang, $L=50 \mathrm{~cm}$ dan tinggi $H=$ $45 \mathrm{~cm}$.

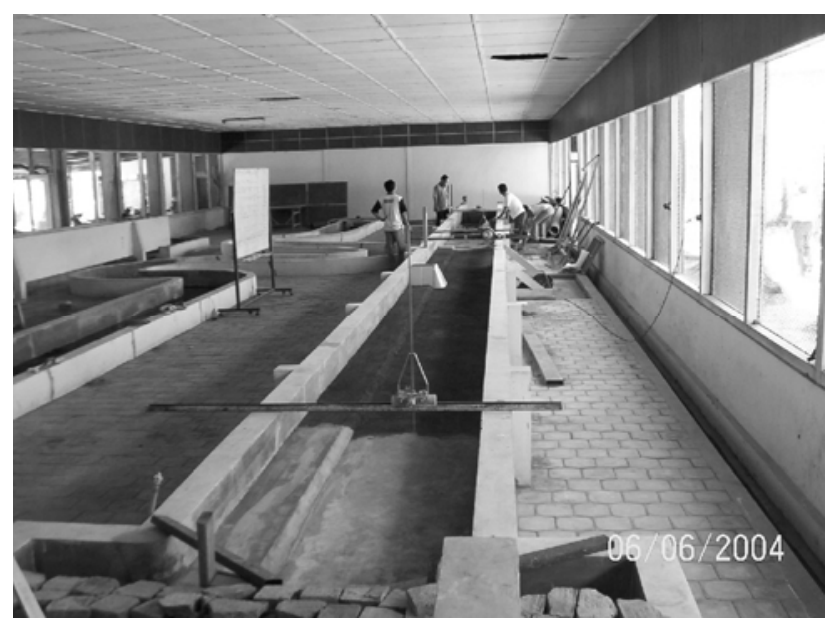

Gambar 2. Foto saluran flume berbentuk majemuk dengan abutmen 


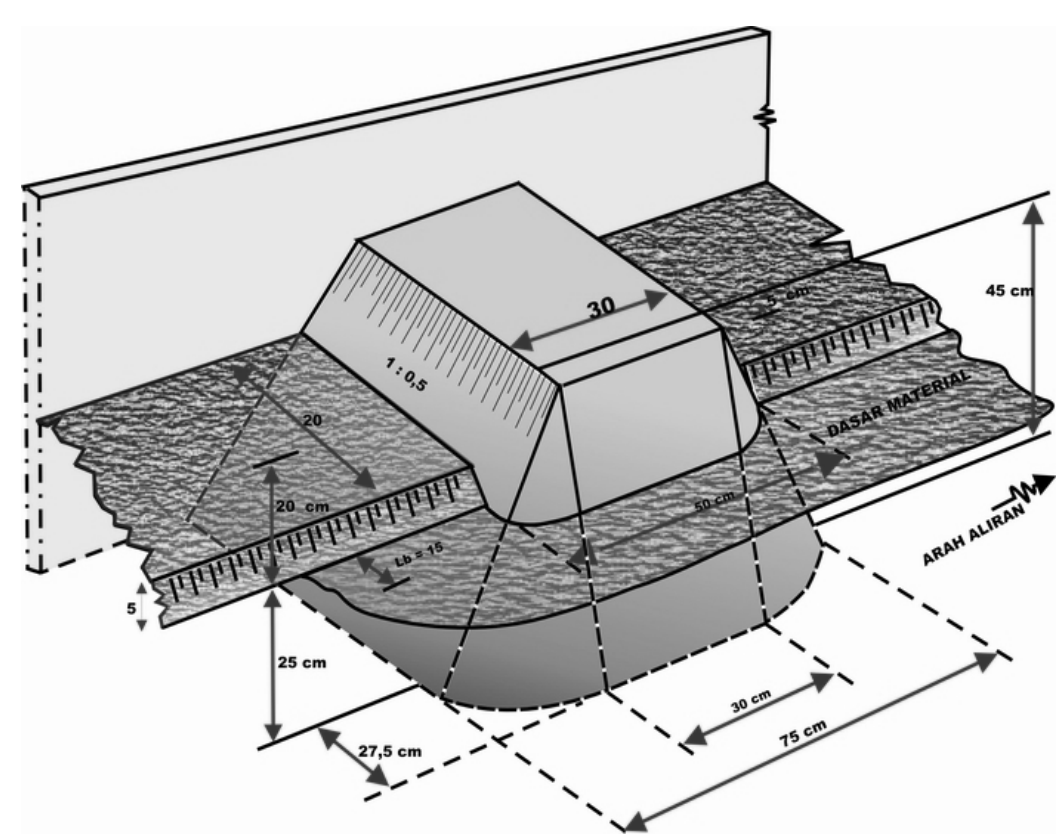

Gambar 3. Model abutmen tipe spilltrough.

Model saluran berbentuk tampang saluran majemuk (lihat Gambar 3) dengan lebar bantaran $20 \mathrm{~cm}$, tinggi bantaran $5 \mathrm{~cm}$, kemiringan tepi bantaran 1:1. Dalam penelitian ini diambil untuk tampang saluran dengan rentang aspect ratio $\mathrm{B} / \mathrm{h}_{0}>5$ (dengan $\mathrm{B}=$ lebar bentang saluran, ho = kedalaman aliran), hal ini dimaksudkan untuk menghindari pengaruh gesekan pada dinding saluran. ${ }^{12}$ Pengukuran dilakukan selama 360 menit untuk 1 running, dengan posisi pengamatan terdiri dari 9 titik pengamatan (lihat Gambar 4). Penelitian ini dilakukan sebanyak 10 running dengan 1 running pendahuluan. Running pendahuluan dilakukan untuk mengetahui kondisi aliran clear water scour atau live-bed scour.

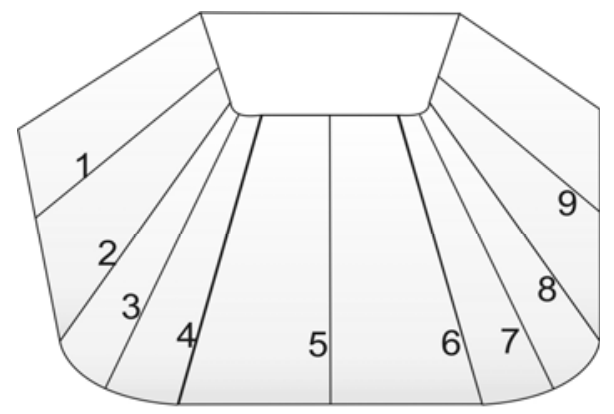

Gb. Posisi Ttitik Pengamatan Kedalaman Gerusan pada Abutmen

Gambar 4. Posisi titik-titik pengamatan pada tipe spilltrough

Penelitian dilakukan sebanyak 10 running dengan petimbangan bahwa jumlah running sudah dapat mewakili gambaran dari hasil scouring yang memungkinkan grafik mendekati smoot dan debit tidak terlalu besar (maksimum $30 \mathrm{l} / \mathrm{det}$ ) dengan pertimbangan kemudahan pengukuran dan tidak terlalu cepat penggerusannya, serta waktu dan biaya yang dikeluarkan menjadi bahan pertimbangan. Penelitian ini adalah merupakan sebagian dari penelitian total yang juga meliputi pada kondisi aliran live-bed scour dengan jumlah running yang sama, serta dilanjutkan dengan penelitian tipe model lain (wing-wall abutment) yang tidak dibahas pada tulisan ini.
Pada penelitian ini, variabel yang diukur secara langsung adalah debit aliran (Q) sebanyak 10 debit (melalui alat ukur debit Thompson, dapat dilihat pada Tabel 2), kedalaman gerusan $d_{s}$ (dengan menggunakan tongkat ukur berskala) untuk 9 posisi pengamatan untuk tiap-tiap waktu tertentu yang berkesinambungan sampai mencapai 360 menit, lihat gambar 4. Kemudian setelah selesai running diukur panjang lubang gerusan $(\mathrm{P})$ dan lebar lubang gerusan (L), serta menggambar konturnya secara skalatis. Demikian pula sebelumnya sudah diadakan analisis gradasi sedimen untuk mengetahui sifat keseragaman butiran (uniformity).

\section{HASIL DAN PEMBAHASAN}

\section{Gerusan Pada Tipe Spilltrough Dengan Kondisi Clear Water Scour}

Kedalaman gerusan yang terjadi pada kondisi clearwater scour pada abutmen tipe spilltrough adalah merupakan kedalaman gerusan yang lebih kecil bila dibandingkan dengan live-bed scour untuk tipe abutmen yang sama. Pengukuran kedalaman gerusan pada kondisi clear-water scour dilakukan selama 360 menit. Pada pengukuran tersebut, kedalaman gerusan maksimum terjadi pada posisi di titik 3 , sedangkan pada posisi titik 1 dan 9 tidak terjadi degradasi, hal ini terdapat pada sisi awal bantaran. Grafik hasil gerusan seperti yang ditunjukkan pada Gambar 5, adapun data pengukuran dapat dilihat pada Tabel 1. Sedangkan kontur 2D diperlihatkan pada Gambar 6, dan kontur 3D diperlihatkan pada Gambar 7.

Berdasarkan Gambar 5 dan Gambar 6 ternyata gerusan terjadi dimulai pada ujung abutmen sebelah hulu, kemudian berkembang sepanjang sisi abutmen ke arah hilir. Gerusan terus berlangsung hingga membentuk lubang gerusan (scour hole) yang dalamnya cenderung mengalami pendangkalan ke arah hilir. Sedangkan di bagian hilir lubang gerusan terutama dibagian pinggir, terjadi pengendapan sedimen (deposition). 


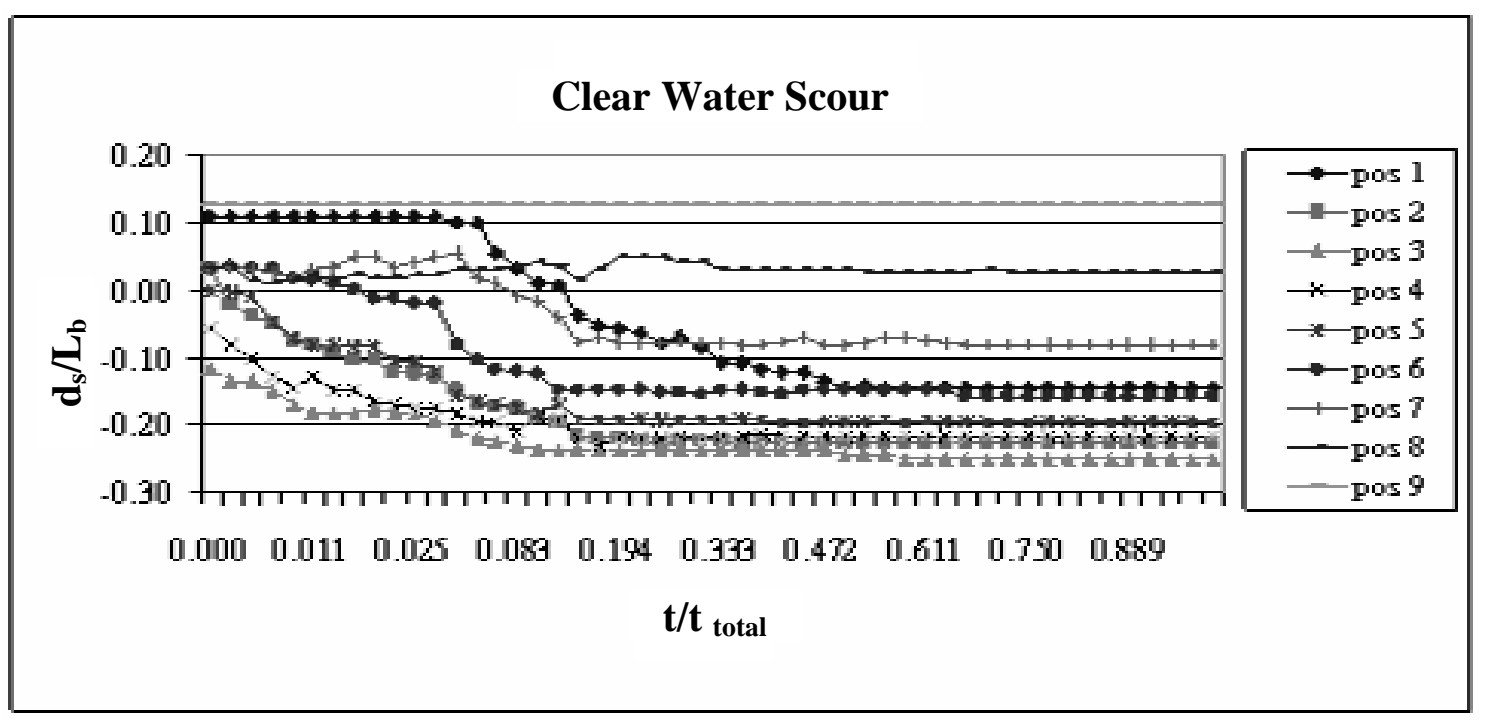

Gambar 5. Hubungan $\left(\mathrm{t} / \mathrm{t}_{\text {total }}\right)$ dengan $\left(\mathrm{d}_{\mathrm{s}} / \mathrm{L}_{\mathrm{b}}\right)$ Kondisi Clear-Water Scour pada Sembilan Posisi Titik Pengamatan.

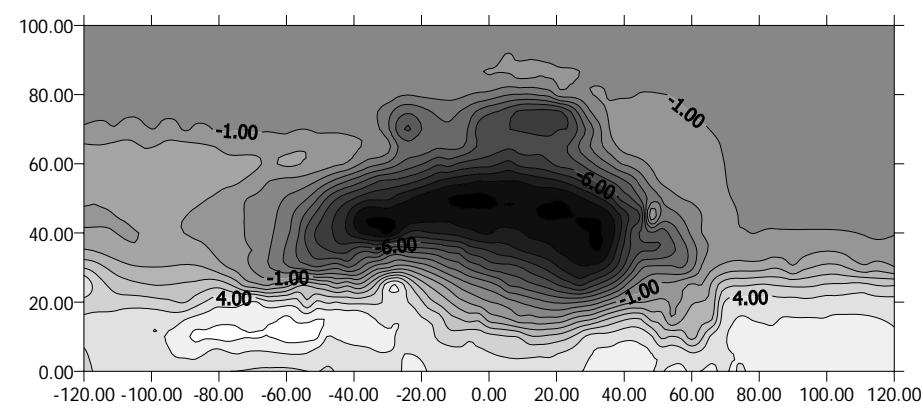

Gambar 6. Kontur Permukaan Gerusan Tanpa Proteksi Pada kondisi Clear-Water Scour untuk Q = 30 lt/ detik.

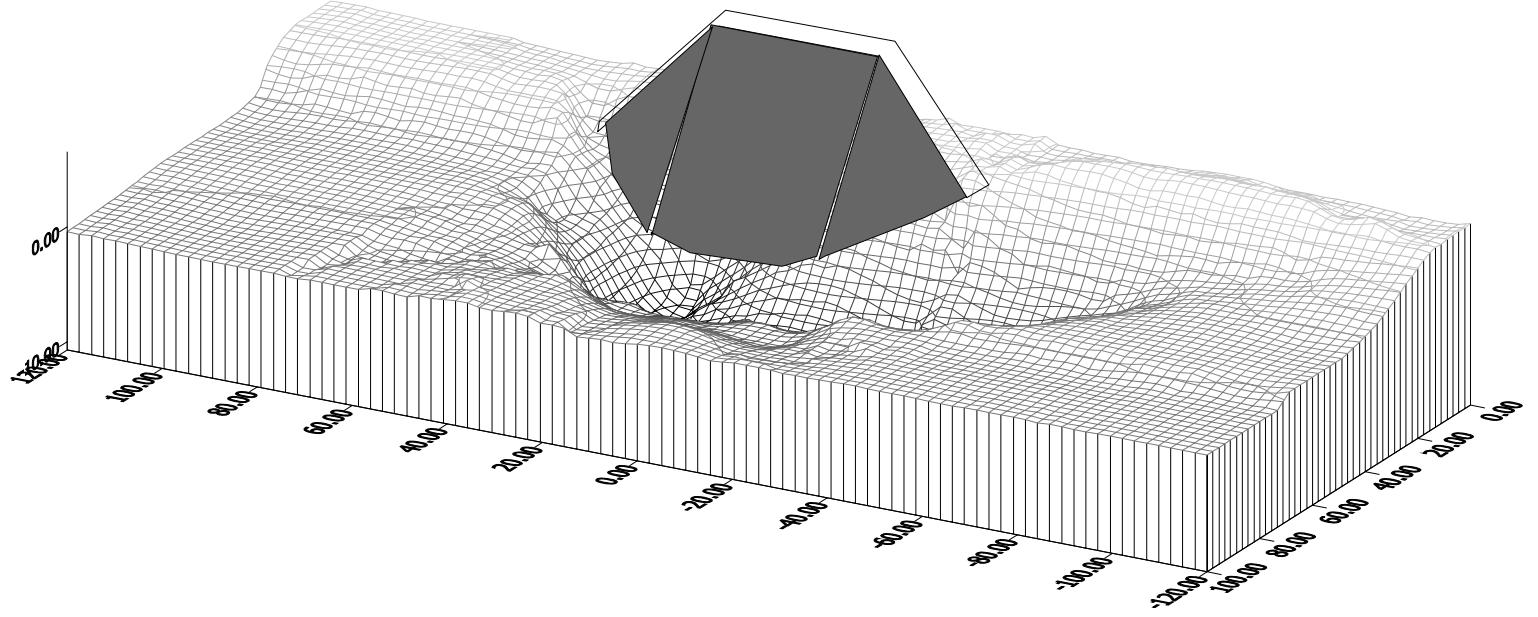

Gambar 7. Gambar Tiga Dimensi Kontur Clear-Water Scour untuk Q=30 lt/detik.

Pengendapan ini berkembang terus hingga akhirnya tererosi kembali kebagian hilir, akhirnya terkumpul serta endapan bertambah di bagian hilir dan semakin panjang seiring dengan bertambahnya waktu. Pada grafik Gambar 5 terlihat bahwa kedalaman gerusan maksimum (yang terdalam) terjadi di posisi titik 3, dimana pada posisi ini aliran mengalami separasi maka dapat dikatakan posisi ini sebagai titik separasi (separation point), sebagian aliran mengalami gerakan lurus dan membentur abutmen kemudian turun kebawah dan sebagian aliran memisah dengan membelok.

Ketika aliran membetur abutmen dan turun ke bawah, aliran mengadakan gerusan terhadap dasar saluran dan kemudian sedimen yang tergerus akan diangkut oleh aliran yang membelok dan bergerak ke hilir, sehingga pada titik ini gerusan mengalami kedalaman yang maksimum atau dikatakan yang terdalam diantara posisi titik-titik pengamatan. 
Adapun gambar kontur gerusan 3D tanpa proteksi pada tipe spilltrough dengan kondisi aliran clear-water scour diperlihatkan pada Gambar 7.

Berdasarkan kajian fungsi Breusers dan Raudkivi, ${ }^{5}$ lihat persamaan 2 dan 3 di atas, dari data running dapat diperoleh grafik hubungan kedalaman gerusan relatif terhadap angka Reynold seperti pada Gambar 8.

Pada Gambar 8 terlihat adanya pengaruh kecepatan dan lebar abutmen terhadap kedalaman gerusan yang dapat dinyatakan dengan persamaan berikut:

$$
\frac{d_{s}}{L_{b}}=9.10-15\left(\frac{U \cdot L_{b}}{v}\right)^{2,6399}
$$

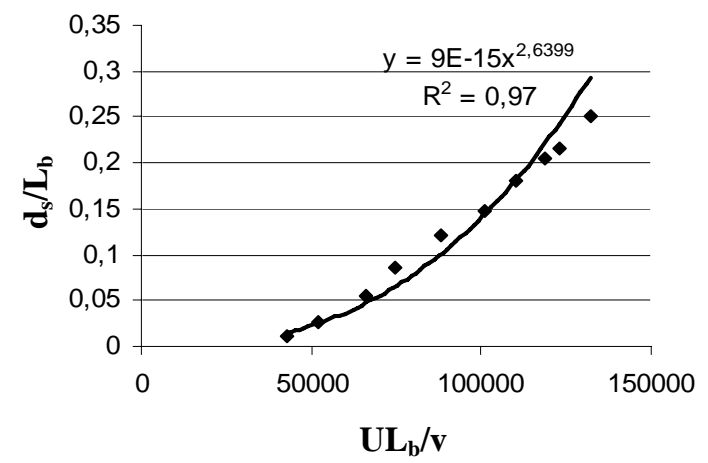

Gambar 8. Hubungan $\left(\frac{d_{s}}{L_{b}}\right)$ dengan $\left(\frac{U L_{b}}{v}\right)$ pada kondisi Clear Water - Scour

Berdasarkan grafik Gambar 8 dan persamaan (7) tersebut disimpulkan bahwa semakin besar kecepatan aliran dan semakin lebar panjang abutmen akan semakin besar kedalaman gerusannya. Jika kedalaman relative gerusan ditinjau hubungannya dengan kecepatan geser dapat dilihat pada Gambar 9.

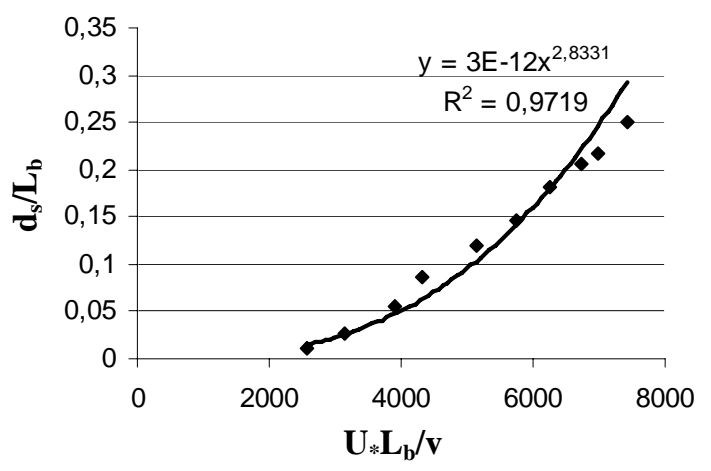

Gambar 9. Hubungan $\left(\frac{d_{S}}{L_{b}}\right)$ dengan $\left(\frac{U_{*} L_{b}}{v}\right)$ pada kondisi Clear Water - Scour

Pada Gambar 9 terlihat adanya pengaruh dari kecepatan geser dan lebar abutmen terhadap kedalaman gerusan yang dapat dinyatakan dengan persamaan berikut:

$$
\frac{\mathrm{d}_{\mathrm{s}}}{\mathrm{L}_{\mathrm{b}}}=3.10-12\left(\frac{\mathrm{U}_{*} \cdot \mathrm{L}_{\mathrm{b}}}{\mathrm{v}}\right)^{2,8331}
$$

Adapun grafik hubungan kedalaman gerusan relatif terhadap angka Froude diperlihatkan dalam Gambar 10.

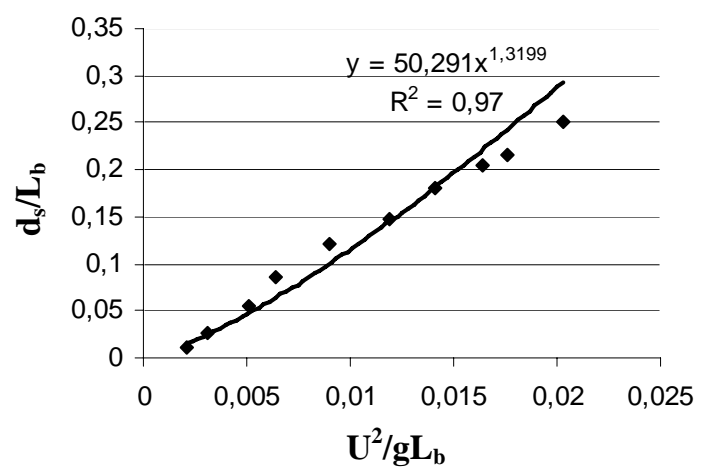

Gambar 10. Hubungan $\left(\frac{d_{s}}{L_{b}}\right)$ dengan $\left(\frac{U^{2}}{g L_{b}}\right)$ pada kondisi Clear Water - Scour

Pada Gambar 10 terlihat adanya pengaruh kecepatan, lebar abutmen dan gravitasi terhadap kedalaman gerusan yang dapat dinyatakan dengan persamaan berikut:

$$
\frac{\mathrm{d}_{\mathrm{s}}}{\mathrm{L}_{\mathrm{b}}}=50,291\left(\frac{\mathrm{U}^{2}}{\mathrm{~g} \cdot \mathrm{L}_{\mathrm{b}}}\right)^{1,3199}
$$

Jika kedalaman gerusan relative terhadap kedalaman aliran dihubungkan dengan angka froud butiran, maka dapat diperlihatkan pada Gambar 11.

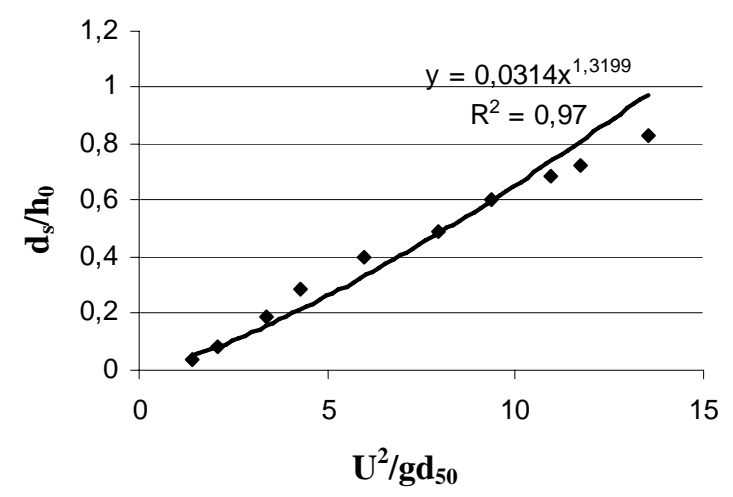

Gambar 11. Hubungan $\left(\frac{\mathrm{d}_{\mathrm{s}}}{\mathrm{h}_{\mathrm{o}}}\right)$ dengan $\left(\frac{\mathrm{U}^{2}}{\mathrm{gd}_{50}}\right)$ pada kondisi Clear Water - Scour

Berdasarkan Gambar 11, maka diperoleh persamaan hubungan antara kedalaman relatif gerusan dengan angka Froude butiran sebagai berikut:

$$
\frac{\mathrm{d}_{\mathrm{s}}}{\mathrm{h}_{\mathrm{o}}}=0,0314\left(\frac{\mathrm{U}^{2}}{{\mathrm{~g} . \mathrm{d}_{50}}^{2}}\right)^{1,3199}
$$

Berdasarkan persamaan (7), (8), (9) dan (10) di atas, maka kedalaman gerusan pada kondisi Clear Water Scour mempunyai kriteria yaitu dipengaruhi oleh angka Reynold abutmen baik karena aliran maupun butiran, 
angka Froude abutmen, angka Froude butiran dan kedalaman relative aliran. Maka kedalaman gerusan pada kondisi clear-water scour secara umum mempunyai kriteria yaitu sangat dipengaruhi oleh kecepatan aliran, kecepatan gesek, kekentalan aliran, lebar dasar abutmen, gravitasi aliran, diameter rata-rata butiran dan kedalaman aliran.

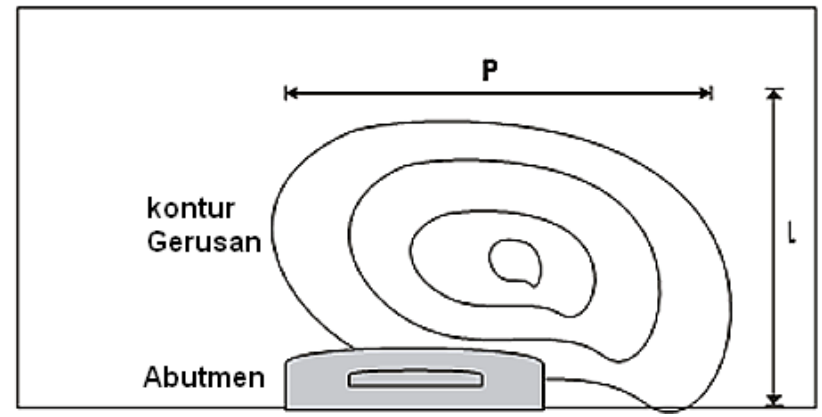

Gambar 12. Sketsa Lubang Gerusan

\section{Kajian Lubang Gerusan}

Mengenai kajian lubang gerusan (scour-hole), gerusan terjadi dimulai pada ujung abutmen sebelah hulu, kemudian berkembang sepanjang sisi abutmen sampai bagian hilir. Gerusan terus berlangsung hingga membentuk lubang gerusan (scour hole) yang dalamnya cenderung mengalami pendangkalan ke bagian hilir. Sedangkan di bagian hilir lubang gerusan terutama dibagian pinggir, terjadi pengendapan sedimen (deposition) sementara, pengendapan ini berkembang terus hingga akhirnya tererosi kembali kebagian lebih hilir, akhirnya terkumpul serta endapan bertambah di bagian hilir lubang gerusan dan semakin panjang seiring dengan bertambahnya waktu. Lubang gerusan tersebut membentuk setengah sepatu tapal kuda (a half horseshoe) seperti yang terlihat pada Gambar 12.

Adapun data hasil pengukuran lebar lubang gerusan (L) dan panjang lubang gerusan (P) serta hubungannya dapat dilihat pada Tabel 2. Berdasarkan data tersebut dapat diperoleh gambar grafik hubungan antara kecepatan relatif aliran $\left(\mathrm{U} / \mathrm{U}_{*}\right)$ terhadap lebar relatif lubang gerusan $\left(\mathrm{L} / \mathrm{d}_{\mathrm{s}}\right)$ pada kontur kedalaman gerusan di sekitar abutmen jembatan yang dapat dilihat pada Gambar 13.

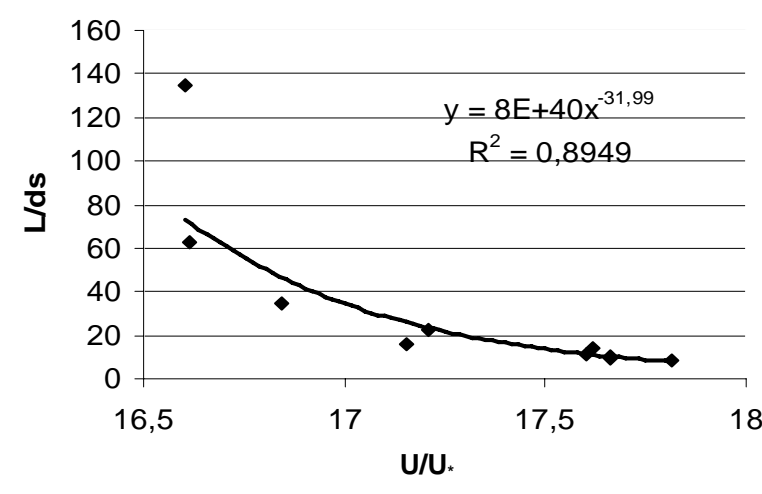

Gambar 13. Hubungan $\mathrm{L} / \mathrm{ds}$ dengan $\mathrm{U} / \mathrm{U}_{*}$ pada kondisi clear-water scour

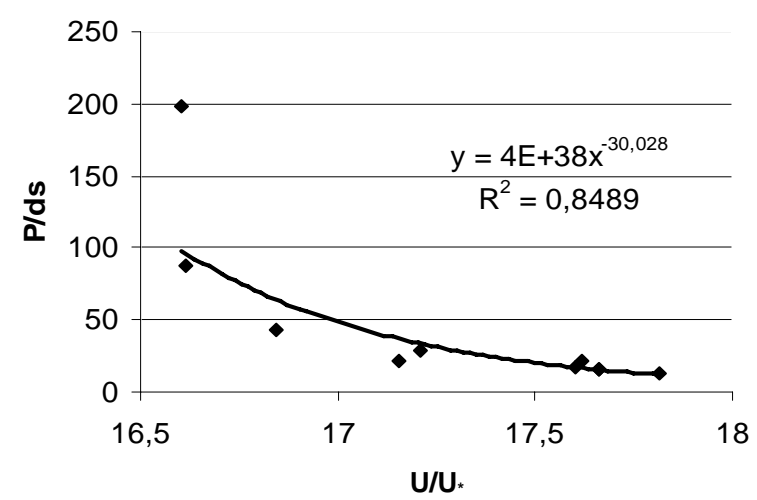

Gambar 14. Hubungan $\mathrm{P} / \mathrm{ds}$ dengan $\mathrm{U} / \mathrm{U}$ * pada kondisi clear-water scour

Berdasarkan Gambar 13, maka diperoleh persamaan hubungan antara kecepatan relatif dengan lebar relatif lubang gerusan sebagai berikut:

$$
\frac{\mathrm{L}}{\mathrm{d}_{\mathrm{S}}}=8.10\left(\frac{\mathrm{U}}{\mathrm{U}_{*}}\right)^{-31,99}
$$

Demikian juga hubungan antara kecepatan relatif aliran $\left(\mathrm{U} / \mathrm{U}_{*}\right)$ terhadap panjang relatif lubang gerusan $\left(\mathrm{P} / \mathrm{d}_{\mathrm{s}}\right)$ pada kontur kedalaman gerusan di sekitar abutmen jembatan dapat ditunjukkan pada Gambar 14, dan hubungan tersebut dapat dinyatakan dalam persamaan sebagai berikut:

$$
\frac{\mathrm{P}}{\mathrm{d}_{\mathrm{S}}}=4.1038\left(\frac{\mathrm{U}}{\mathrm{U}_{*}}\right)^{-30,028}
$$

Berdasarkan persamaan (11) dan (12), terlihat bahwa terdapat hubungan yang erat antara kecepatan aliran dengan besarnya lebar maupun panjang lubang gerusan disekitar abutmen jembatan pada kondisi clear-water scour. Hubungan yang diperlihatkan oleh persamaan (11) dan (12), menunjukkan bahwa besarnya lubang gerusan (scour hole) baik panjangnya maupun lebarnya sangat dipengaruhi oleh besarnya kecepatan aliran, kecepatan gesek dan kedalaman gerusan.

\section{KESIMPULAN}

Berdasarkan kajian di atas dapat disimpulkan sebagai berikut.

1. Proses gerusan yang terjadi pada abutmen tipe spilltrough pada saluran majemuk berjalan dari hulu ke hilir di sekitar tubuh abutmen. Gerusan mempunyai kedalaman maksimum di titik separasi aliran (tepat di hulu kaki abutmen) dan mempunyai kecenderungan kedalaman gerusan yang semakin dangkal ke arah hilir yang pada akhirnya terjadi pengendapan sedimen di hilir abutmen. Pengendapan ini berkembang terus hingga kemudian tererosi kembali ke bagian hilir, akhirnya terkumpul serta endapan bertambah di bagian hilir dan semakin panjang seiring dengan bertambahnya waktu. 
2. Kedalaman gerusan maksimum pada kondisi clearwater scour pada titik separasi aliran (point of separation) yaitu posisi titik-3 untuk tipe abutmen spill-trough. Sedangkan agradasi terjadi pada posisi titik-9.

3. Proses kedalaman gerusan untuk kondisi clear-water scour pada akhirnya akan sampai kepada kedalaman gerusan yang mencapai keseimbangan pada waktu tertentu.

4. Berdasarkan kajian persamaan fungsi menunjukkan bahwa terdapat hubungan yang erat antara kedalaman gerusan dengan angka Reynold dan angka Froude aliran. Sehingga kedalaman gerusan sangat dipengaruhi oleh kecepatan aliran, kecepatan gesek, kedalaman aliran, kekentalan aliran, gravitasi aliran dan lebar dasar abutmen. Semakin besar kecepatan aliran atau semakin lebar dasar abutmen atau juga semakin tinggi kedalaman aliran akan menyebabkan semakin besarnya kedalaman gerusan.

5. Kontur gerusan di sekitar abutmen mempunyai bentuk yang hampir sama untuk semua debit aliran yaitu lubang gerusan berbentuk setengah sepatu kuda. Besarnya lubang gerusan sangat dipengaruhi oleh besarnya kecepatan aliran, kecepatan gesek, dan kedalaman gerusan, yang mempengaruhi ukuran panjang maupun lebar lubang gerusan.

\section{UCAPAN TERIMA KASIH}

Penulis mengucapkan terima kasih atas seluruh pembiayaan penelitian ini yang merupakan bagian dari Research Grant Program Hibah Technological and Professional Skills Development Sector Project (TPSDP), Direktorat Jendral Pendidikan Tinggi Departemen Pendidikan Nasional, Jakarta untuk Tahun Anggaran 2004 Batch III di Jurusan Teknik Sipil Fakultas Teknik Universitas Muhammadiyah.

\section{DAFTAR PUSTAKA}

1. Hoffmans, G. J. C. M.; and Verheij, "Scour Manual", A.A. Balkema, Rotterdam, 1997.
2. Legono, D., “Gerusan pada Bangunan Sungai”, PAU Ilmu-Ilmu Teknik Universitas Gadjah Mada, Yogyakarta, 2001.

3. Rawiyah dan Yulistiyanto, "Gerusan Lokal di Sekitar Dua Abutmen dan Upaya Pengendaliannya", Jurnal Dinamika Teknik Sipil Vol. 7 No. 2 - Juli 2007, Penerbit Jurusan Teknik Sipil UMS, Surakarta, 2007.

4. Raudkivi, A. J.; and Ettema, R., "Clear-Water Scour at Cylindrical Piers", Journal of Hydraulic Engineering, Vol. 109, No. 3, pp. 338-350, ASCE, New York, 1983.

5. Breusers, H. N. C.; and Raudkivi, A. J., "Scouring", IAHR Hydraulic Structure Design Mannual, A.A. Balkema, Rotterdam, 1991.

6. Hanwar, S, "Gerusan Lokal di Sekitar Abutmen Jembatan", Tesis S2 Program Pasca Sarjana UGM, Yogyakarta, 1999.

7. Rinaldi, "Model Fisik Pengendalian Gerusan di Sekitar Abutmen Jembatan”, Tesis S2, Program Pasca Sarjana UGM, Yogyakarta, 2002.

8. Abdurrosyid, Jaji, "Kajian Pengendalian Gerusan di Sekitar Abutmen Jembatan Pada Kondisi Adanya Angkutan Sedimen", Tesis S2, Program Pasca Sarjana UGM, Yogyakarta, 2004.

9. Melville, B. W., "Bridge Abutment Scour In Compound Channels", Journal of Hydraulic Engineering, Vol 121, No. 12, pp. 863-868. ASCE, New York, 1995.

10. Abdurrosyid, Jaji, dkk. "Kajian Pengendalian Gerusan di Sekitar Abutmen Jembatan Pada Kondisi Ada dan Tidak Ada Angkutan Sedimen Untuk Saluran Berbentuk Majemuk", Laporan Penelitian Research Grant, TPSDP Batch-III 2004 , DP2M DIKTI Dep.Pendidikan Nasional, 2006.

11. Garde, R. J.; and Raju, K. G. R., "Mechanics of Sediment Transportation and Alluvial Stream Problem”, Willy Eastern Limited, ed $11^{\text {st }}$ New Delhi, 1998.

12. Kironoto, B. A.; and Graf, W. H., "Turbulence Characteristics in Rough Uniform Open-Channel Flow", Journal of Water Maritime and Energy, Vol. 112, Issue 4, London, 1995. 